
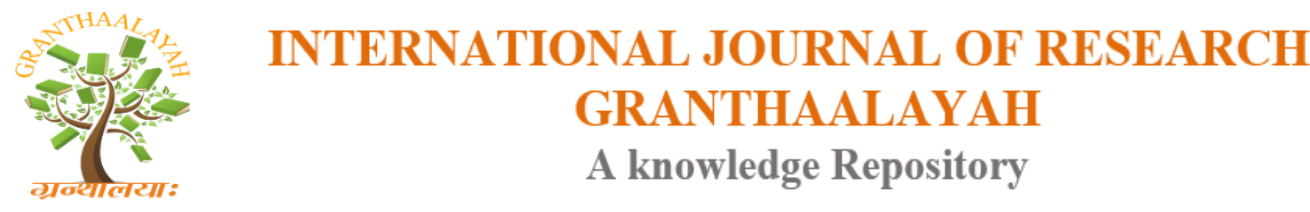

Social

\title{
THE ANALYSIS AND DESIGN OF GUIDED INQUIRY E-WORKSHEET BASED TO DEVELOP HIGH ORDER THINKING SKILLS
}

\author{
Beli Riyadi $^{* 1}$, Chandra Ertikanto ${ }^{2}$, Agus Suyatna ${ }^{2}$ \\ ${ }^{1}$ Physics Education Department, University of Lampung, J1. Prof. Dr. Sumantri Brojonegoro No. \\ 1 Lampung, Indonesia
}

\begin{abstract}
The aims of this research were to analyze the needs and to design electronic worksheet to develop High Order Thinking Skills (HOTS) in static fluid material at Islamic High School Ar Raihan and SMAN 6 Bandar Lampung. The research method used in this study was two steps of Research and Development (R\&D) with mixed methods. Step 1: analyze the needs by doing: (a) front end analysis including analyze the needs of teachers and students, and (b) learner analysis which focused on students' HOTS with pre experimental design i.e. one shot case study. Step 2: make hypothetic design of e-Worksheet through Focus Group Discussion (FGD). The study results show the information from front analysis that the analysis of teachers need is $75 \%$ hasn't mastered the newest multimedia yet, find difficulties in leading the students to think scientifically, and have not developed appropriate e-worksheet. The analysis of students need shows that $72 \%$ students were interested in electronic learning media, $88 \%$ hasn't be familiar with experiment method and there is no appropriate e-worksheet as they wished yet. Learner analysis shows that Sign 2 tailed 0,000 $<0,05$ so that the students mostly don't have HOTS yet. Finally, tested design is obtained from Guided Inquiry based e-worksheet to develop HOTS.
\end{abstract}

Keywords: E-Worksheet; Guided Inquiry; High Order Thinking Skills.

Cite This Article: Beli Riyadi, Chandra Ertikanto, and Agus Suyatna. (2018). "THE ANALYSIS AND DESIGN OF GUIDED INQUIRY E-WORKSHEET BASED TO DEVELOP HIGH ORDER THINKING SKILLS." International Journal of Research - Granthaalayah, 6(7), 223-233. https://doi.org/10.29121/granthaalayah.v6.i7.2018.1302.

\section{Introduction}

Rapid development in the work environment not only requires school graduates have extensive knowledge but also have professional skills ready to use in employment. This fact requires that governments and schools continually need to improve the quality of graduates in order to have the desired competencies. UNESCO (United Nations Educational, Scientific and Cultural Organization) states that the competencies which must be possessed by students are: (1) Knowledge, (2) Skills in performing tasks professionally (to do), (3) Ability to perform in the field of science/profession (to be), and (4) Ability to utilize the field of science for the common interest 
of the ethical (to live together) [1]. This is in harmony with [2] the development of science and technology brings great impact on various aspects of life, including education. Education is very important because the quality of human resources can only be highly established and maintained through a good education system. This reason is in line with the demand that the education system needs to be updated continuously in accordance with the development of other aspects of life in order to create creative and innovative intelligence, and have the right character according to the needs of the world. Besides, [3] reveals that the School should try to be an open space for innovative ideas.

Education plays an important role in advancing technology; the more advanced the education the more advanced the technology. One that plays a major role in the field of technology is Physics. The advanced Physics has spawned a variety of advanced technologies such as Internet networks are faster, more efficient agricultural tools, and others. Physics is a branch of natural science using numbers or calculations (mathematical) to study the natural parts, interactions and physical phenomena of nature [4]

Physics is still a difficult thing to understand by students so that to produce graduates with the competence required by UNESCO, the School conduct continuous improvement of the learning model, learning media and teaching materials applied in the learning process in the classroom.

Learning model applied in the learning process must be in accordance with the needs and conditions of students at a school and must be adjusted to students. Just like the subjects of Physics if it is taught using lectures method, it will actually make the students difficult to understand when it is compared using a scientific way. Also, learning History will certainly make students difficult if it is studied in a scientific way instead of lecture methods.

Beside the learning models, the thing should be considered is the teaching materials. Teaching materials are the resources a teacher uses to deliver instructions. Each teacher requires a range of tools to draw upon in order to assist and support student in learning. These materials play a large role in making knowledge accessible to a learner and can encourage a student to engage with knowledge in different ways. The teaching materials that are still a favorite used in the international world are in the form of Students worksheet. Worksheet is a kind of printed instructional material that is prepared and used by teachers. Worksheets are written materials related to the activities [5] [6].

Various countries have been long time used the Students Worksheet. Indonesia has been decades using the Students Worksheet. Turkey, as far as Turkey and Turkish educational literature is concerned; worksheets can be considered as a new term. Indeed, worksheets were used in education until 1990s, but they were not called worksheets. They were called exercise notebooks (in Turkish "temrin defterleri"), tests, drawings, etc. After the reorganization policies of education in Turkey in 1990s, scholars tended to explore and introduce contemporary educational technologies and materials to the public [7]. Duration of application of Students Worksheet not necessarily make maximum result in learning process, we will prove from both countries above that is Indonesia and Turkey. According to updated results on the countries ranked on Math and science, Indonesia is ranked of 69th out of 76 participating countries, means that Indonesia which has implemented student worksheets in a long time is still in the top 10 position last sequence. 
Turkey is in a better position than Indonesia which is ranked 41. Both countries are intensively applying worksheets students have not been able to penetrate the top 15 positions. Ineffectiveness or effectiveness of student worksheets should be well studied to match the expectations of teachers and students, so that students not only have low order Thinking skills (LOTS) but also High Order Thinking Skills (HOTS). HOTS is using the thinking to find new challenge [8] [9].

Based on the above explanation, the researcher will perform the analysis and design of the Students Worksheet in the hope of becoming an example for the teachers to be able to work in creating teaching materials as needed so that it can grow students HOTS,

\section{Research Method}

The research method used in this study is the 2 first steps of Research and Development (R\&D) of ADDIE (Analysis, Design, Development, Implementation, and Evaluation) with mixed methods. Mixed methods Research is an approach to inquiry that combines or associated both qualitative quantitative forms of research [10].

Step 1 Define, including

(a) Front end Analysis including need analysis of learning media, learning mode and learning materials of 4 teachers (2 teachers of SMA 6 Bandar Lampung and 2

teachers SMA IT Ar Raihan), 25 students (12 students of SMA 6 Bandar Lampung and 13 students of SMA IT Ar Raihan) by spreading questionnaires then analysed using Guttman scale.

(b) Learner analysis focused on High Order Thinking Skills of 25 students with pre-experimental design i.e. one shot case study. One Shot Case Study is a research design which consist of a group of variables which given treatment then observed the result [11]. HOTS test has been conducted using multiple choices questions about Statistical Fluid which validity and reability have been tested. These are the indicators of HOTS which has been tested:

Table 1: Indicators of Hots Questions

\begin{tabular}{|c|l|}
\hline NO & \multicolumn{1}{|c|}{ Indicator of Questions } \\
\hline $\mathbf{1}$ & Assessment of Factual Knowledge \\
\hline $\mathbf{2}$ & Assessment of Factual Knowledge \\
\hline $\mathbf{3}$ & Analysis of Declarative Metacognitive Knowledge \\
\hline $\mathbf{4}$ & Analysis of Procedural Knowledge \\
\hline $\mathbf{5}$ & Analysis of Conditional Metacognitive Knowledge \\
\hline $\mathbf{6}$ & Analysis of Factual Knowledge \\
\hline $\mathbf{7}$ & Assessment of Conditional Metacognitive Knowledge \\
\hline $\mathbf{8}$ & Analysis of Declarative Metacognitive Knowledge \\
\hline $\mathbf{9}$ & Assessment of Procedural Knowledge \\
\hline $\mathbf{1 0}$ & Assessment of Declarative Metacognitive Knowledge \\
\hline
\end{tabular}

Students' answers were then analysed using SPSS 21.0 to test the following hypothesis: 


\section{Research hypothesis}

H0: Students don't have High Order Thinking Skills yet

H1: Students already have High Order Thinking Skills

Statistical hypothesis:

$\mathrm{H} 0: \mu \geq \mu 0$

$\mathrm{H} 1: \mu<\mu 0$

$(\mu 0=75)$

The 2nd step, Design, is making the hypothetical design of E-Worksheet by Focus Group Discussion with 4 Physics teachers. Focus Group Discussion (FGD) is a rapid assessment, semi structured data gathering method in which a purposively selected set of participants gather to discuss issues and concern based on a list of key themes drawn up by the researcher or FGD is related to qualitative research which used to provide researchers with data which are not obtainable through documentation or record. Also, it referred to as group interviewing, is essentially a qualitative research methodology [12] [13] [14].

\section{Result of Study}

Step 1: Define

\section{Front End Analysis}

Front End Analysis is the process of gathering information in preparation for the design, development and implementation of a program or project. This step performs front end analysis on Physics teacher and students in both schools. The following exposures will show the results of analysis of instructional media, learning models and student worksheets.

Table 2: The Result of Learning Media or Multimedia Analysis on Teacher

\begin{tabular}{|c|l|c|c|}
\hline No & \multicolumn{1}{|c|}{ Indicators } & \multicolumn{2}{c|}{ Percentage (\%) } \\
\cline { 3 - 4 } & & Yes & No \\
\hline $\mathbf{1}$ & Utilize Personal Computer (PC) & 100 & 0 \\
\hline $\mathbf{2}$ & Implementation of newest multimedia & 50 & 50 \\
\hline $\mathbf{3}$ & Application of multimedia and learning material collaboration & 25 & 75 \\
\hline $\mathbf{4}$ & Variation of multimedia percentage & 25 & 75 \\
\hline $\mathbf{5}$ & Availability of interactive learning media & 50 & 50 \\
\hline $\mathbf{6}$ & Difficulties in developing interactive learning media & 100 & 0 \\
\hline
\end{tabular}

The results show that the overall teachers utilize the PC but has not been intensively in applying new multimedia due to the rarely Get supply from the government, $75 \%$ of teachers do not yet have a varied multimedia and have not been able to collaborate multimedia with or as teaching materials. Overall, teachers find it difficult to develop interactive learning media

Table 3: The Result of Learning Media Analysis or Multimedia on Students

\begin{tabular}{|c|l|c|c|}
\hline \multirow{2}{*}{ No } & \multicolumn{1}{|c|}{ Indicators } & \multicolumn{2}{c|}{ Percentage (\%) } \\
\cline { 3 - 4 } & & Yes & No \\
\hline $\mathbf{1}$ & Variation of learning media & 38 & 72 \\
\hline $\mathbf{2}$ & Have Personal Computer & 80 & 20 \\
\hline $\mathbf{3}$ & Intensity of getting modules & 100 & 0 \\
\hline
\end{tabular}




\begin{tabular}{|c|l|c|c|}
\hline \multirow{2}{*}{ No } & \multicolumn{1}{|c|}{ Indicators } & \multicolumn{2}{c|}{ Percentage (\%) } \\
\cline { 3 - 4 } & & Yes & No \\
\hline $\mathbf{4}$ & Intensity of getting Student Worksheets & 100 & 0 \\
\hline $\mathbf{5}$ & Get software/multimedia & 60 & 40 \\
\hline $\mathbf{6}$ & Get interesting software/multimedia & 36 & 64 \\
\hline $\mathbf{7}$ & Get software/multimedia which ease individual learning & 48 & 52 \\
\hline $\mathbf{8}$ & Get software/multimedia which fasten learning process & 60 & 40 \\
\hline $\mathbf{9}$ & Get practical software/multimedia & 0 & 100 \\
\hline $\mathbf{1 0}$ & Get innovative software/multimedia & 24 & 76 \\
\hline $\mathbf{1 1}$ & Get software/multimedia interesting to see & 12 & 88 \\
\hline $\mathbf{1 2}$ & Get software which difficult to use & 44 & 56 \\
\hline $\mathbf{1 3}$ & Interested to try new software/multimedia & 100 & 0 \\
\hline
\end{tabular}

The result of learning media analysis on students shows the potential that $80 \%$ of students have Personal Computer, but the learning media is still $72 \%$ feel it isn't varied, while in other thing is quite balance experienced by students. It is of particular concern that students feel the multimedia learning that is used so far is not practical, students are happy with the multimedia they consider new.

Multimedia is a delivery system by using various types of learning materials that form a unit or package [15]. In detail, multimedia is a combination of several media in the form of text, images, graphics, sound, animation, video, and interaction into a single unit that together displays information, messages, or lesson content that has been packaged into digital files (computerized) to Users [16] Multimedia is currently the most popular is interactive multimedia, interactive multimedia is a popular multimedia used in the learning process in various countries.

Today, use of multimedia-based educational program is getting more popular in many areas of learning and training as it stimulates new ways in information delivery with the concerns of accessibility, reusability and individualization to fulfil the needs for different types of learners, but not just limited to conventional teaching and learning methods. However, it is challenging to produce a good courseware as the development requires more studies and planning in incorporating multimedia enabled learning methods into the existing practices without creating unnecessary frustration in the learning process [17] [18].

One of the multimedia learning that has not been utilized in both schools and can be a solution in overcoming multimedia learning that is Kvisoft Flipbook Maker. Kvisoft Flipbook Maker is interactive multimedia software to create PDF files (Portable Document Format) into flash pages, each PDF page can be flip (back and forth) like a real book. This software will convert PDF files such as online magazines, e-newspapers, online catalogs, digital books, and other publications for online sharing. Kvisoft proved to be a good virtual flipbook and worthy of use so that learning materials become very easily understood effectively even to the critical thinking skills of students. This is because the operation is very easy, the elements of music and animation are considered very positive for students [19] [20]. 
Table 4: Result of Students Worksheet Analysis on Teacher

\begin{tabular}{|c|l|c|c|}
\hline \multirow{2}{*}{ No } & \multicolumn{1}{|c|}{ Indicators } & \multicolumn{2}{|c|}{ Percentage (\%) } \\
\cline { 3 - 4 } & & Yes & No \\
\hline $\mathbf{1}$ & Student Worksheets contain practicum activities & 0 & 100 \\
\hline $\mathbf{2}$ & Effectiveness of Students Worksheets & 25 & 75 \\
\hline $\mathbf{3}$ & High level thinking skills of Students Worksheet & 25 & 75 \\
\hline
\end{tabular}

The results of Students Worksheet analysis used nowadays at School don't contain practicum activities, but it is less effective and leads students to think highly are still fairly not maximaL.

Table 5: Result of Students Worksheet Analysis on Students

\begin{tabular}{|c|l|c|c|}
\hline NO & \multicolumn{1}{|c|}{ Indicators } & \multicolumn{2}{|c|}{ Percentage } \\
\cline { 3 - 4 } & & Yes & No \\
\hline $\mathbf{1}$ & Teacher use learning material in learning process & 100 & 0 \\
\hline $\mathbf{2}$ & Availability of learning material can motivate students' interest & 32 & 68 \\
\hline $\mathbf{3}$ & Student Worksheets are used effectively & 44 & 56 \\
\hline $\mathbf{4}$ & Student Worksheets contain practicum activities & 0 & 100 \\
\hline $\mathbf{5}$ & Student Worksheets contain questions which help students & 80 & 20 \\
\hline
\end{tabular}

The results of worksheets analysis on students indicate that the teaching materials are still a favorite use in the learning process. Students' worksheets provide helpful questions in learning, but students do not get students worksheets that there are practicum activities.

Based on the analysis on the teachers and students above, which is still the subject matter on the Worksheet of Students so far that the Students Worksheet still has not loaded the lab activities. This is in line with the problems that occur in the learning model is still a lack of scientific learning.

Table 6: Result of Learning Model Analysis on Teacher

\begin{tabular}{|c|l|c|c|}
\hline No & \multicolumn{1}{|c|}{ Indicators } & \multicolumn{2}{c|}{ Percentage (\%) } \\
\cline { 3 - 4 } & & Yes & No \\
\hline $\mathbf{1}$ & Students activeness in Physics learning process & 50 & 50 \\
\hline $\mathbf{2}$ & Students activeness in discussion & 25 & 75 \\
\hline $\mathbf{3}$ & Apply scientific approach actively & 25 & 75 \\
\hline $\mathbf{4}$ & Students opportunity level to respond & 100 & 0 \\
\hline $\mathbf{5}$ & Students' activity to prove theories with facts. & 25 & 75 \\
\hline $\mathbf{6}$ & Students ability to formulate and prove experimental hypothesis & 0 & 100 \\
\hline $\mathbf{7}$ & Individual learning & 0 & 100 \\
\hline
\end{tabular}

The result of the above learning model analysis which needs more attention is the students' ability to formulate and prove the experimental hypothesis as well as the independent study according to the teacher is still very low, besides the $75 \%$ students are not actively discussing or doing scientific approach. 
Table 7: Result of Learning Model Analysis on Students

\begin{tabular}{|c|l|c|c|}
\hline NO & \multicolumn{1}{|c|}{ Indicators } & \multicolumn{2}{c|}{ Percentage (\%) } \\
\cline { 3 - 4 } & & Yes & No \\
\hline $\mathbf{1}$ & Delivered method is interesting and easy to understand & 80 & 20 \\
\hline $\mathbf{2}$ & Find difficulties in learning Physics & 84 & 16 \\
\hline $\mathbf{3}$ & Begin the learning with challenging questions & 48 & 52 \\
\hline $\mathbf{4}$ & Opportunities to deliver opinion & 16 & 84 \\
\hline $\mathbf{5}$ & Opportunities to discuss certain topic & 12 & 88 \\
\hline $\mathbf{6}$ & Opportunities to prove answers through experiment & 0 & 100 \\
\hline $\mathbf{7}$ & Guided to conduct experiment & 12 & 88 \\
\hline
\end{tabular}

The result of the analysis of the learning model in the students shows that $80 \%$ stated that the accepted method is interesting and easy to understand, but $84 \%$ still find difficulties in understanding the material of physics and expressing opinion. Interesting thing to note is that students feel unable to prove the answer experimentally and guided in doing the experiment.

Based on the analysis of learning models in teachers and students above, the main problems that occur are the low ability and opportunities of students in formulating and proving the experimental hypothesis. It means that condition states the need for physics learning using a scientific approach or method.

The scientific method is a body of techniques for investigating phenomena, acquiring the new knowledge, or correcting and integrating previous knowledge [21]. One of the things that the researcher considered as correct way to solve the problem of learning model above is the inquiry learning model. This statement suited with [22] These actions should initiate solidly founded changes in our students' vision of science education, leading to a didactic knowledge base that is coherent with school inquiry-based approaches.

Inquiry-based science education is considered to be an important current trend in science education reform. Scientific inquiry generally refers to the diverse ways in which scientists study the natural world [23]. More than a procedure or a method, it is a process of investigating how, why or what, and then making sense of the resultant findings [24]. Besides, Inquiry learning 'refers to the activities of pupils in which they develop knowledge and understanding of scientific ideas, as well as an understanding of how scientists study the natural world' than Inquiry teaching is defined as 'providing a classroom where learners can engage in scientific-oriented questions to formulate explanations-based on evidence' [25]. The inquiry is a way of acquiring knowledge with the results of their own business through activities of scientific investigation [26].

Inquiry-Based Learning is devided into some levels. [27] for example, used the amount of information given to students to define levels of inquiry. They proposed a four-level model: at the first level, the question, procedures, and solution are all provided to the students. At the second level, the solution is not given. At the third level, both the methods and the solution are not given. At the highest level, information about the questions, the procedures, and the solution are all generated by the students. however, to create maximum learning atmosphere, appropriate guidance from teacher in inquiry is strongly needed. So, it is more accurately if guided inquiry is implemented. Inquiry-based Learning is defined as 'the creation of a classroom where students are 
engaged in essentially open-ended, student-centered, hands-on activities'. (Colburn, 2000; Butterm, etc. 2014)

One way to conceptualise inquiry-based learning is that it is a student-centric pedagogical approach characterised by activities. Guided Inquiry terbukti efektif dalam membimbing students dalam proses pembelajaran [27] [28] [29] [30] [31] [32] [33].

\section{Learner Analysis}

Learner analysis is the description of the target population. We analyze learners to discover their characteristics that impact learning and instruction. Common tools used to find out more about learners include.

One-Sample Statistics

\begin{tabular}{|l|r|r|r|c|}
\hline & $\mathrm{N}$ & Mean & Std. Deviation & $\begin{array}{c}\text { Std. Error } \\
\text { Mean }\end{array}$ \\
\hline Nomor & 25 & 13.0000 & 7.35980 & 1.47196 \\
HOTS & 25 & 62.5600 & 13.51567 & 2.70313 \\
\hline
\end{tabular}

One-Sample Test

\begin{tabular}{|c|c|c|c|c|c|c|}
\hline & \multicolumn{6}{|c|}{ Test Value $=75$} \\
\hline & \multirow[b]{2}{*}{$t$} & \multirow[b]{2}{*}{$\mathrm{df}$} & \multirow[b]{2}{*}{ Sig. (2-tailed) } & \multirow[b]{2}{*}{$\begin{array}{c}\text { Mean } \\
\text { Difference }\end{array}$} & \multicolumn{2}{|c|}{$\begin{array}{l}95 \% \text { Confidence Interval of the } \\
\text { Difference }\end{array}$} \\
\hline & & & & & Lower & Upper \\
\hline Nomor & -42.121 & 24 & .000 & -62.00000 & -65.0380 & -58.9620 \\
\hline HOTS & -4.602 & 24 & .000 & -12.44000 & -18.0190 & -6.8610 \\
\hline
\end{tabular}

Figure 1: One Simple T Test

The data above shows value of Sig. (2-tailed) obtained is $0,000<0.05$. If the value of sig. $<$ Critical limit of 0.05 , then $\mathrm{H} 0$ is rejected and $\mathrm{H} 1$ is received. Then, it is achieved the information that Students do not have High Order Thinking Skills yet.

\section{Step 2: Design}

Good hypothetical design which takes into account the problems that occurs so can become solution in achieving the learning process. Based on the problems and discussions that have been done on the front end analysis, the hypothetical designs that researchers and teachers produced in the FGD is utilizing Kvisoft Flipbook Maker into Electronic Students Worksheet-based on Guided Inquiry to Grow HOTS students. The following designs are obtained:

Table 8: Hypothetical Design

\begin{tabular}{|l|l|l|c|}
\hline NO & \multicolumn{1}{|c|}{ Content } & \multicolumn{1}{c|}{ Description } & $\begin{array}{c}\text { HOTS } \\
\text { Activities }\end{array}$ \\
\hline $\mathbf{1}$ & $\begin{array}{l}\text { Finding } \\
\text { Problem }\end{array}$ & $\begin{array}{l}\text { Showing video about a physical phenomenon then } \\
\text { asking question or problem }\end{array}$ & \\
\hline $\mathbf{2}$ & Asking & $\begin{array}{l}\text { Giving temporary answers for the question or problem } \\
\text { solution which can be tested using data }\end{array}$ & \\
\hline
\end{tabular}




\begin{tabular}{|c|c|c|c|}
\hline 3 & Investigating & Conducting experiment & \\
\hline 4 & $\begin{array}{l}\text { Collecting } \\
\text { data }\end{array}$ & Data collected can be in form of table, graphic, etc & Analysing \\
\hline 5 & Discussing & $\begin{array}{l}\text { Testing the hypnotises which have been formulated by } \\
\text { conducting data analysis }\end{array}$ & Evaluating \\
\hline 6 & Reflecting & $\begin{array}{l}\text { Students decide, estimate, predict, speculate, and } \\
\text { explain by making conclusion based on data and } \\
\text { analysis }\end{array}$ & Creating \\
\hline
\end{tabular}

The Guided Inquiry step which was applied above is in accordance with the Guided Inquiry (according to [34] [35] Bloom's Revised Taxonomy [36] which has six cognitive domains positioned Cognitive Remembering, Understanding and Applying as LOTS, while the top 3 Cognizes are analysis, evaluation and creating as HOTS The essence of HOTS is in terms of guided inquiry It is clear that cultivate the ability to analyze, evaluate, and create[37]. Guided inquiry is very appropriate in growing HOTS because its application has produced many positive results on the learning process, and HOTS is the highest achievement in the learning process requires a model of learning scientific guidelines such as guided inquiry in demanding the ability but No and fully released by the teacher so as to achieve maximum results. A good design is the design obtained by reviewing all aspects of the learning process with accuracy in analyzing and determining the design to achieve solution.

\section{Conclusion}

In the define stage it takes a new multimedia that is considered so that the solution is kvisoft flipbook maker, required Students Worksheet and scientific learning model so that the solution is guided inquiry, students who average not have HOTS can be overcome by designing LKS Electronic based guided inquiry due guidance Teachers in the scientific process can grow HOTS in students maximally.

\section{Acknowledgements}

The article is based on work conducted by the last two authors in science education at University of Lampung. We thank all the teachers and students who participated in this study.

\section{References}

[1] Yuberti, Laporan dan Hasil Penelitian Pengembangan Media Pembelajaran Fisika Berbasis Kvisoft Flipbook Maker yang Merujuk Pada Nilai-Nilai Keislaman Di Perguruan Tinggi Negeri Bandar Lampung (IAIN Raden Intan Lampung, Bandar Lampung, 2015), pp. 1

[2] R. M. Probosari. Improvement of Students' Scientific Writing of Biology Education of Sebelas Maret University Through Reading Project Based Learning in Indonesian Journa. Solo: JPII 4 (1) (2015), pp. 31-35.

[3] C. Kettanun. Project-based Learning and Its Validity in a Thai EFL Classroom. Bangkok: Social and Behavioral Sciences 192 (2015), pp. 567-573.

[4] Kusminarto, Esensi Fisika Modern (Andi, Yogyakarta, 2011), pp. 1. 
[5] S. Kurt. \& A. R. Akdeniz. Fizik Öğretiminde Enerji konusunda Geliştirilen Çalışma Yapraklarının Uygulanması. ODTÜ Eğitim Fakültesi V. Fen Bilimleri ve Matematik Eğitimi Kongresi, 16-18 Eylül, Ankara (2002).

[6] U. Töman. Ali Riza Akdeniz. Sabiha Odabaşi Çimer. Fatih Gürbüz. Extended Worksheet Developed According to 5E Model Based on Constructivist Learning Approach. International Journal on New Trends in Education and Their Implications October 2013 Volume: 4 Issue: 4 Article: 16 ISSN 1309-6249

[7] S. Kaymakc1. A review of Studies on Worksheet in Turkey. Turkey: US-China Education Review A 1 (2012), pp. 57-64

[8] M. D. Kusuma, Undang Rosidin. Agus Suyatna. (2017) The Development of Higher Order Thinking Skill (Hots) Instrument Assessment In Physics Study, Indonesia: IOSR Journal of Research \& Method in Education (IOSR-JRME) e-ISSN: 2320-7388,p-ISSN: 2320-737X Volume 7, Issue 1 Ver. V (Jan. - Feb. 2017), pp. 26-32

[9] Y.M. Heong., Othman, W.D., Md Yunos, J., Kiong, T.T., Hassan, R., \& Mohamad, M.M. 2011. The Level of Marzano Higher Order Thinking Skills Among Technical Education Students. International Journal of Social and humanity, Vol. 1, No. 2, July 2011, 121125.

[10] Cresswell, John W. Research Design; Qualitative, Quantitative, and Mixed Methods Approaches, Sage, Los Angeles. (2009)

[11] Sugiono. Metodologi penelitian pendidikan pendekatan Kuantitatif Kualitatif dan R\&D. Bandung. Alfabeta. (2012)

[12] Ab Aziz, N. (2015) Role of Focus Group Discussion (FGD) in e-Business Research. Open Access Library Journal, 2: e1281. http://dx.doi.org/10.4236/oalib.1101281

[13] P. Y. Byers. and Wilcox, J.R. Focus Groups: A Qualitative Opportunity for Researchers. Journal of Business Communication, 28, (1991), pp. 63-78

[14] B, William. Evaluating the Efficacy of Focus Group Discussion (FGD) in Qualitative Social Research, International Journal of Business and Social Science, Vol. 3 No. 7; April 2012.

[15] M. W. Hadibin. Pembangunan Media Pembelajaran Teknik Komputer Jaringan Kelas X Semster Ganjil Pada Sekolah Menengah Kejuruan Taruna Bangsa Pati Berbasis Multimedia Interaktif. IJCS-Indonesian Jurnal on Computer Science - Speed - FTI UNSA - ijcss.unsa.ac.id. ISSN: 19799330 (Print) - 2088-0154 (Online) - 2088-0162 (CDROM) (2013)

[16] N. L. Karmila. (2017) Pengembangan Multimedia Interaktif Materi Budaya Hidup Sehat dalam Pembelajaran Pendidikan Jasmani, Olahraga Dan Kesehatan di SMA. e-Journal PJKR Universitas Pendidikan Ganesha Jurusan Pendidikan Jasmani, Kesehatan, dan Rekreasi (Vol 8, No 2, Tahun 2017)

[17] F. T. Leow. Interactive Multimedia Learning: Innovating Classroom Education in a Malaysian University. TOJET: The Turkish Online Journal of Educational Technology - April 2014, volume 13 issue 2 (2014)

[18] F. Martin. \& Klein, J.D. Effects of Objectives, Practice, and Review in Multimedia Instruction. Journal of Educational Multimedia and Hypermedia, 17 (2), (2008), pp. 171-189.

[19] Z. Wijayanto. Muhammad S. Pengembangan E-Modul Berbasis FlipBook Maker dengan Model Project Based Learning untuk Mengembangkan Kemampuan Pemecahan Masalah Matematika, Indonesia: Prosiding Sains and Mathematic Forum 2014. ISBN 978-602-0960-00-5

[20] Rasiman. Pramasdyahsari, Agnita Siska. (2014) Development of Mathematics Learning Media EComic Based on Flip Book Maker to Increase the Critical Thinking Skill and Character of Junior High School Students, Indonesia: International of Education and Research, Volume 2.

[21] A.F. Goldhaber, M. M. Nieto. "Photon and graviton mass limits", Rev. Mod. Phys., American Physical Society, 82: 939, doi:10.1103/RevModPhys.82.939. (2010), pp. 939-79.

[22] Abell, S. Research on science teacher knowledge. In S. Abell \& N. Lederman (Eds), Handbook of Research on science education (pp. 1105-1149). New Jersey: Lawrence Erlbaum Associates. (2007) 
[23] L. L. Liang, \& Richardson, G.M. Enhancing prospective teachers' science teaching efficacy beliefs through scaffolded, student-directed inquiry. Journal of Elementary Science Education, 21, (2009), $\mathrm{pp} / 51-66$

[24] S. Bhattacharyya., Volk, T., \& Lumpe, A. (2009). The influence of an extensive inquiry-based field experience on pre-service elementary student teachers' science teaching beliefs. Journal of Science Teacher Education, 20, 199-218. doi:10.1007/s10972-009-9129-8

[25] G.R. Luera, G.R., \& Otto. Development and evaluation of an inquiry-based elementary science teacher education program reflecting current reform movements. Journal of Science Teacher Education, 16, (2005), pp. 241-258.

[26] C. Ertikanto,.., I, Wahyudi. Viyanti. Inmprovement of Teacher Inquiry Capacity Through Teacher Training Program Based on Inquiry and Science Teaching. Indonesian Journal of Science Education. JPII 4 (2) (2015), pp. 142-148

[27] R. L. Bell., Smetana, L., \& Binns, I. Simplifying inquiry instruction. The Science Teacher, 72(7). (2005) pp, 30-33.

[28] Colburn, A. An inquiry primer. Science Scope, 23(6). (2000) Pp, 42-44.

[29] T. Butterm, Tassane (2014) Do Different Levels of Inquiry Lead to Different Learning Outcomes? A comparison between guided and structured inquiry. International Jurnal of Science Education. Vol. 36, No. 12, 1937-1959,

[30] H. Banchi,, \& Bell, R. The many levels of inquiry. Science and Children, 46(2),. (2008). pp, 2629.

[31] B. L. Buck., Bretz, S. L., \& Towns, M. H. Characterizing the level of inquiry in the undergraduate laboratory. Journal of College Science Teaching, 38(1), (2008). pp, 52-58.

[32] M. D. Herron. The nature of scientific enquiry. The School Review, 79(2), (1971). pp, 171-212.

[33] H. L. Martin. Defining inquiry: Exploring the many types of inquiry in the science classroom. Science Teacher, 69(2), (2002). pp,34-37

[34] M. Konstelnikova, \& Ozvoldova (2013). Inquiry in Physics Classes by Means of Remote Experiment. Procedia social and Behavioral Sciences, 89, pp. 133.

[35] C. Ertikanto. Development and Evaluation of a Model-Supported Scientific Inquiry Training Program for Elementary Teachers in Indonesia. International Journal of Instruction. Vol.10, No.3 e-ISSN: 1308-1470. www.e-iji.net p-ISSN: 1694-609X (2017)

[36] L. W. Anderson, D. R. Krathwohl, A Taxonomy for Learning, Teaching, and Assessing: A Revision of Bloom's Taxonomy of Educational Objectives. Allyun \& Bacon. Boston, MA (Pearson Education Group) (2001)

[37] A. Zohar., Dori, Y. J. High order thingking skills and low achieving students: are they mutually exclusive. The journal of the Learning Sciences, 12. (2). (2003), pp. 145-181.

\footnotetext{
*Corresponding author.

E-mail address: beliriyadi@ yahoo.co.id
} 